\title{
IMPACT OF TAX INSTRUMENTS ON THE ORGANIC FOOD MARKET IN POLAND
}

\author{
Magdalena Jarczok-Guzy ${ }^{\bowtie}$ \\ University of Economics in Katowice, Poland
}

\begin{abstract}
This article is an analysis and assessment of the impact of tax instruments on the organic food market in Poland. The assessment was made on the basis of primary data obtained by the author as part of a survey conducted on the inhabitants of the Silesian Voivodeship. In Poland, the VAT rates on food vary, depending on the product classification code. They can be $23 \%, 8 \%$ or $5 \%$. Organic food has not been treated exceptionally, while changes introduced in the tax rates in July 2020 for specific foods are quite significant. The impact of these changes on organic food purchases has been determined in the results of the survey. Therefore, the purpose of the article is to assess the impact of the VAT rate on the organic food market in Poland.
\end{abstract}

Key words: organic food, consumption taxes, food market, Value Added Tax

JEL codes: H20, H31, Q18

\section{INTRODUCTION}

Multi-functional agriculture relates to non-market products and services that agriculture delivers with various degrees of jointness with either farm productivity or farm/rural sceneries. Such non-market goods and services generally are connected to national food security, farm conveniences, recreational opportunities, cultural heritage, activity of rural communities, and an extensive range of ecosystem services comprising nutrient recycling, carbon sink, or groundwater recharge [Moon et al. 2017]. Major modifications in food consumption patterns and changes in composition of consumer diets have been a meaningful phenomenon noticed in many parts of the world in recent decades. Some of the most significant changes have been the expanding consumer need for organic, local, environmentally friendly, tenable, and functional foods that offer profits beyond elemental nutrition. In spite of these commonalities in food consumption trends, changeover in dietary patterns has been observed to vary by country mainly because of economic, socio-demographic and cultural contrasts, as well as urbanization and trade liberalization policies [Hovhannisyan et al. 2020].

Organic food is a type of food products produced in accordance with ecological farming (organic, biological, biodynamic), that is, an ecologically, economically and socially sustainable management system formed entirely on natural production methods. By means of stimulating natural production mechanisms, it generates conditions for nourishing, improving prolificacy and enhancing fertility of soil, ensures the healthiness of plant and animal organisms and makes it attainable to gain high-quality agricultural products. The creed of this kind of farming is a resignation from the use of agricultural chemicals for the sake of biological, mechanical or agrotechnical approaches [Angowski and Bujanowicz-Haraś 2019]. 
In the methods of organic food production, all stages and processes connected with its manufacture are continuously assessed and controlled. Every step is essential, from the means of increasing soil quality, through the choice of the plant cultivation procedure, to the selection of farm animals and methods of their rearing, the means applied to food processing, the labelling of products, and the appropriate transportation to places of sale or distribution [Kacprzak and Wielewska 2019]. In a lot of situations, organic food producers are small farmers. Even though there is a great consumer demand for their products, smaller farms have difficulties competing for a share of this growing market. Despite the fact that marketing channel challenges vary by product and setting, restrictions from limited available quantities, logistic factors and lack of price competitiveness have a negative influence on the capability of smaller producers to supply this market. Among these restrictions, the relative inability of smaller in comparison with larger farms to transport, distribute, and deliver their product is a crucial marketing challenge [Willis et al. 2016].

During the last decade, a lot of research has been carried out around the world to study the eagerness of consumers to pay a price premium for different ecological products. Therefore, according to a global survey by the Nielsen company in 2015, for 30,000 consumers in 60 countries, $66 \%$ of respondents were ready to pay more for ecological goods, a rise of $11 \%$ compared to 2014 and a $16 \%$ increase over the same index in 2013. The Millennial Generation most of all are willing to pay extra - almost $73 \%$ of respondents. Ecological awareness is able to affect the purchase of an ecological product for $45 \%$ of surveyed consumers [Kucher et al. 2019].

From the perspective of the nature of their motivations, three groups of organic food purchasers can be recognized [Łuczka 2019]:

- Consumers who consider organic goods as a basic necessity because of their essential effects; these are the ones who intend to address their central values.

- Consumers for whom it is very crucial to look for harmony with the environment because it gives them peace of mind, while also being a method to express their accountable attitudes.

- Consumers led by integrated motivations who recognize the consumption of organic products in a comprehensive way, because the practical value of purchased goods coexists with spiritual values; these are the most educated and most conscientious buyers who strongly believe that harmony with the environment, which is achieved by purchasing organic products, has influence on satisfaction and self-fulfillment.

The organic food market in Poland is systematically developing, but there are some factors which make the development of organic farming difficult, such as: territorial dispersion of farms, low production scale, low consumer income levels, low environmental awareness. After 2004, organic farming in Poland was characterized by a high growth rate in the number of farms and cultivated area. The key causative agent growth processes were supported by European Union funds [Hermaniuk 2018]. There are also situations on the organic food market, where producers take advantage of consumer ignorance and offer information that suggests the organic origin of food, even though it has not been produced in accordance with the requirements of ecological production processes and has not obtained relevant certificates [Nestorowicz 2018].

In Poland, domestic demand for organic food only correlates with a small part of the whole food market. Thus, the Polish organic food market is continuously in a niche. In Poland, net annual spending on organic food is noticed to have increased quickly over the past five years, at a yearly rate of $20 \%$. In 2017 , it was ca. PLN 1.1 billion (VAT included). The fundamental conditions for further development of organic food production involve both opportunities (for instance, increased competitiveness of food producers and processors functioning in this market) and obstructions (such as the absence of well-organized distribution channels and high costs achieved at various stages of the marketing chain, which significantly hinder the ability to convert market potential into a strong competitive position). To develop the organic food market, it is crucial to support the demand and supply side by preparing productive distribution channels and by taking into consideration the unique nature of these channels, as defined by other customer segments [Grzybowska-Brzezińska and Gorlowa 2019].

High prices are an essential factor which restricts the general availability of organic food for consumers. 
Non-organic products are definitely cheaper than their organic counterparts. This fact is related to the weak expansion of the domestic organic food processing sector, a high share of foreign products, and high margins on organic food. High consumption of organic food is especially visible in highly developed European countries. The highest annual levels of organic food consumption per person have been reported in Switzerland (EUR 177), Denmark (EUR 162), Luxembourg (EUR 134), Austria (EUR 127) and Lichtenstein (EUR 100) [Hermaniuk 2018]. The lowest numbers connected with organic food consumption in Europe can be noticed in Central and Eastern European countries, including Poland (EUR 7) [Doba et al. 2019].

In order to decide what information to present to future consumers and how to present it, it can be useful for farmers and retailers to understand the consumer decision-making process together with consumer choices. Decision making is a mental process of collecting information from the outside environment and using it to make a decision. Buyers in a shopping environment are exposed to a lot of clues that can be used to assess the product and make a purchasing decision [Katz et al. 2019].

In empirical studies, a particular challenge is the fact that consumers who commonly purchase organic food have a tendency to choose more vegetables, fruit, wholegrain products and less meat, and are likely to follow healthier dietary patterns. Each of these dietary aspects is connected with a decreased risk for mortality from particular chronic diseases or their incidence. Consumers who regularly purchase organic food are also more physically active and do not usually smoke. However, connections between organic and conventional food consumption and health outcomes need to be carefully adapted to differences in dietary quality and lifestyle aspects, and the probable presence of residual variables needs to be taken into account [Mie et al. 2017].

The impact of changes in VAT rates on purchasing behavior of consumers in the area of organic food is examined in this research article. The most important and significant changes in VAT rates on food that have been introduced since 1 July 2020 are listed in the table.

A favorable change is the standardization in the rate for bread and pastry goods. Before introducing the change, each product may have had a different tax rate depending on the declared expiry date. Since 1 July 2020 , there has also been a reduction in the rate of tax on goods and services for citrus fruit from 8 to $5 \%$.

The impact of the above-described changes on consumer behavior is illustrated in the following research results. It is worth noting that originally, changes to the VAT matrix were to be introduced as early as 1 April 2020. However, due to the COVID-19 pandemic, the government decided to postpone the change implementation deadline in order to give entrepreneurs time to adjust to the new rates.

\section{METHODOLOGY}

Research within this article was conducted with the use of a questionnaire. The questionnaire consisted of 13 closed and semi-open questions and a metric in which respondents were asked about age, sex, education and net income per person in the family. The questionnaire was completed by 154 adults who live in the Silesian Voivodeship. The selection of the sample was disproportionate and deliberate. The study was conducted from February to May 2020 in a direct way by personal contact.

The questions concerned the purchase of organic food, the motives for choosing such food and knowledge about it. The main part of the survey included

Table. Changes in VAT rates effective since 1 July 2020

\begin{tabular}{|c|c|c|}
\hline Product & Rate before the change & Rate after the change \\
\hline Tropical and citrus fruits, some nuts (pistachio, almonds, coconut) & $8 \%$ & $5 \%$ \\
\hline Bread and pastries & $\begin{array}{c}5 \%, 8 \%, 23 \% \\
\text { depending on the expiry date }\end{array}$ & $5 \%$ \\
\hline
\end{tabular}

Source: Author's own elaboration on the basis of Wydawnictwo C.H. Beck [n.d.]. 
questions related to the change in VAT rates for selected food products, which entered into force on 1 July 2020. Respondents were asked their opinion on each of the described changes and their response to these legislative activities. Respondents were also asked about the possible use of tools that would encourage them to choose organic food, with a particular emphasis on fiscal tools.

\section{RESULTS}

At the beginning of the analysis of the obtained results, the characteristics of the research sample was outlined. The vast majority of the respondents were women $(68 \%)$. However, such a distribution of the research sample does not distort the research results, because it is women who are most often responsible for purchasing food in the household. Most of the respondents were people with secondary education (62\%). Respondents with higher education accounted for $29 \%$ of the total sample. Half of the respondents were between the ages of $18-25(53 \%)$. Consumers over the age of 25 also constituted a significant part of the studied population $(47 \%)$. The respondents in the sample are characterized by an average net income per person in the family in the range of PLN 1,001-2,000 (EUR 227-454) - 40\% and PLN 2,001-3,000-29\% (EUR 454-682). Respondents who earn more than PLN 3,001 accounted for $18 \%$.

Figure 1 shows the results of the answers to the first substantive question. It turns out that most of the respondents had bought organic food in the last three months. Among them, 36\% were women. For these variables a $\chi^{2}$ test was used, which is 2.911 at $p=0.233$ and $d f=2$. A test value is lower than the critical value, which means that these data are not statistically significant.

The results of respondents' answers to the question regarding the knowledge about the difference between organic and conventional food should be viewed as positive. Almost $90 \%$ of respondents definitely know or rather know how organic and conventional food differ. Figure 2 illustrates the full range of data.

Healthiness and lack of preservatives are the main and most important reasons for purchasing organic food by the respondents. All the options of respondent choice are presented in Figure 3.

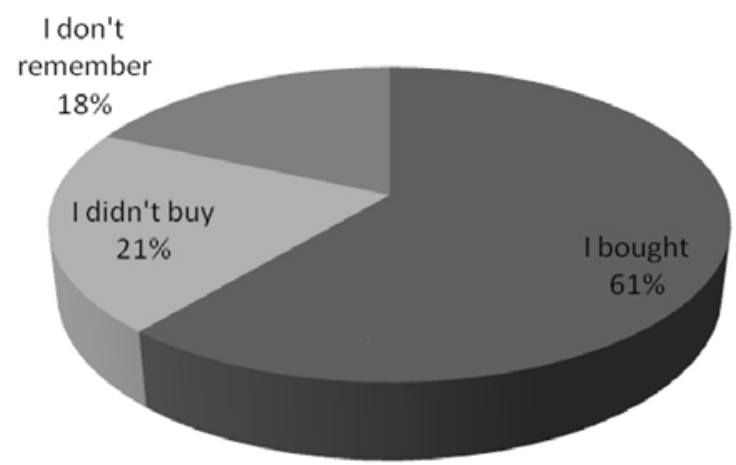

Fig. 1. The purchase of organic food in the last three months

Source: Author's own elaboration on the basis of primary research.

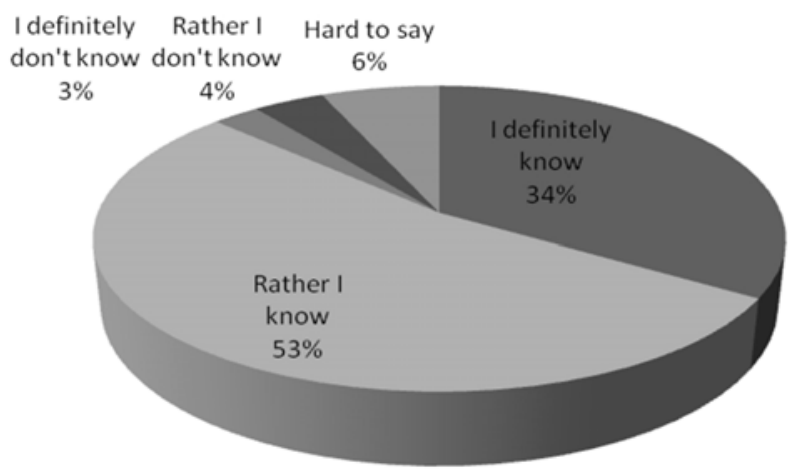

Fig. 2. Knowledge about differences between conventional and organic food

Source: Author's own elaboration on the basis of primary research.

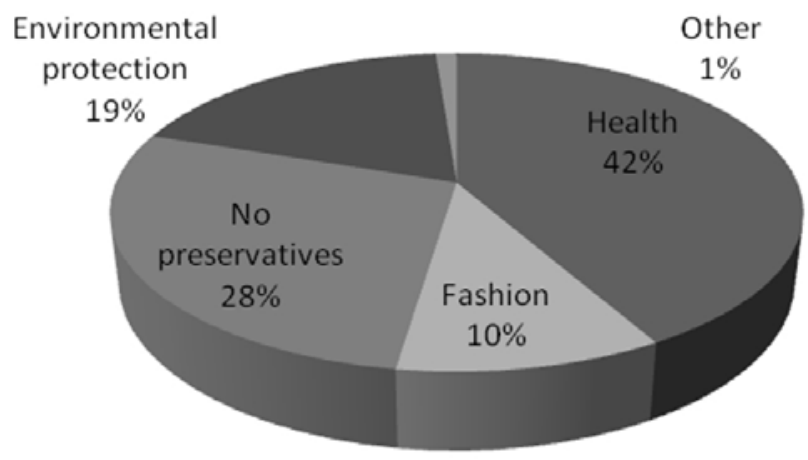

Fig. 3. Motives for buying organic food

Source: Author's own elaboration on the basis of primary research. 
In the next question, respondents were asked to assess the reduction of the VAT rate on bread to the level of $5 \%$, effective since 1 July 2020 . This change was unanimously defined by the respondents as definitely positive and rather positive. The results are illustrated in Figure 4.

Fifty-four percent of respondents with income of PLN 1,001-3,000 estimated the reduction of the VAT rate on bread in a definitely positive way. The detailed distribution of the respondents' answers is shown in Figure 5. Between these variables a correlation coefficient has been calculated, which is in this case 0.55997. A moderate negative correlation here means that with the deteriorating assessment of the change in the rate, the respondents' income decreases.

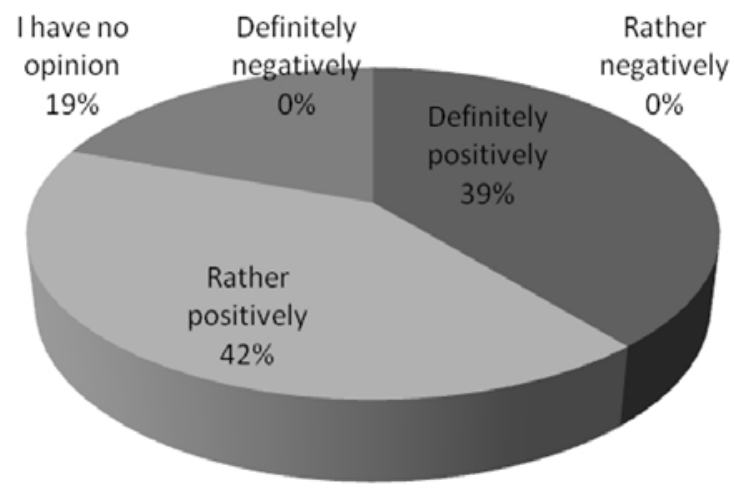

Fig. 4. How do you assess the reduction of the VAT rate on bread up to $5 \%$ since July 2020 ?

Source: Author's own elaboration on the basis of primary research.

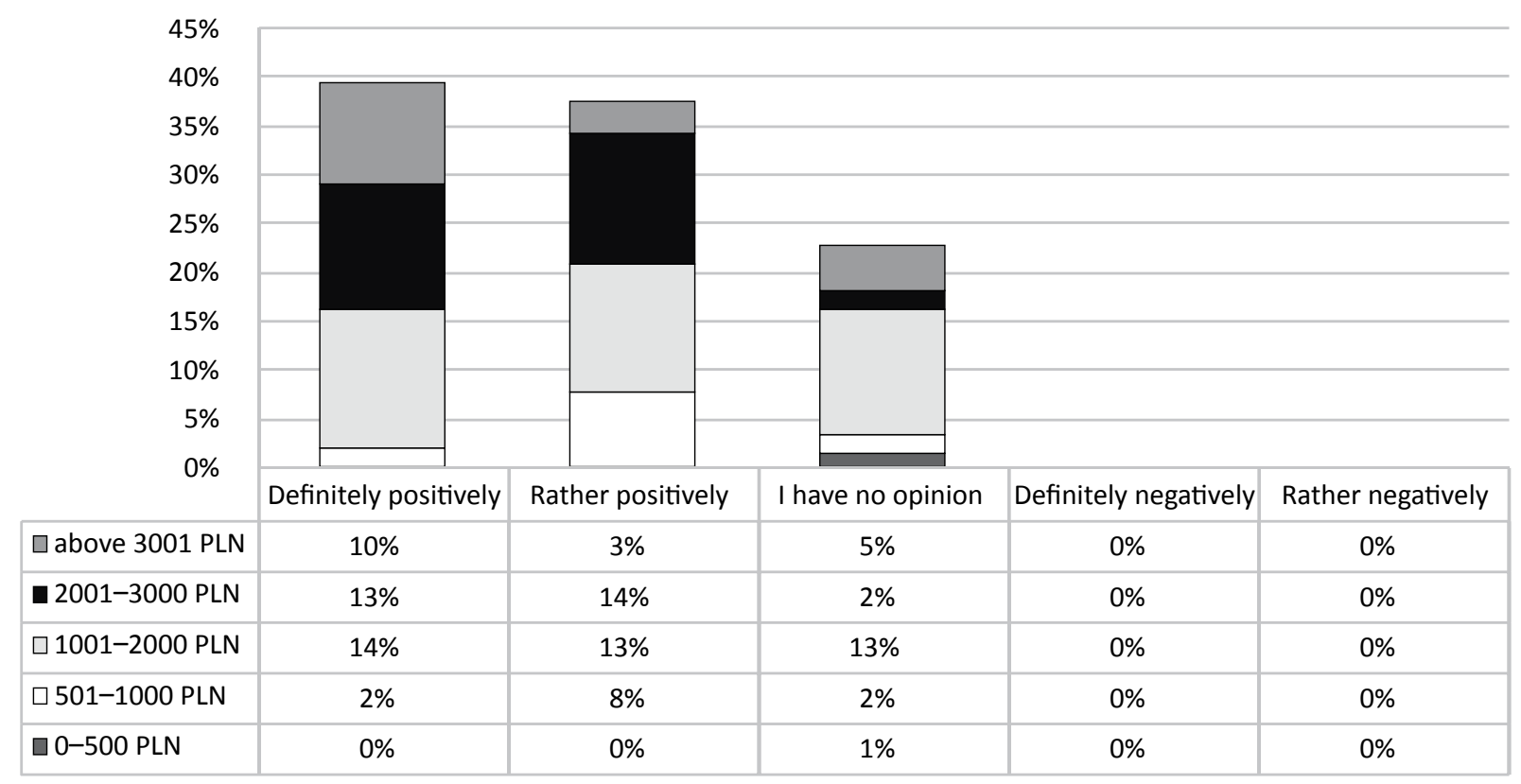

Fig. 5. How do you assess the reduction of the VAT rate on bread up to 5\% since July 2020 ? Due to net income per person in the family

Source: Author's own elaboration on the basis of primary research.

On the other hand, the respondents were unable to assess the impact that a reduction in VAT on bread would have on purchases of organic bread. Only one-third of respondents stated that they would rather buy more organic food than before. Data is illustrated in Figure 6.
Among respondents who did not have an opinion, the largest number were those with a net income per person in the family of PLN 1,001-2,000 (25\%). The correlation coefficient in this set of variables is 0.275471 . It is a very weak dependency which confirms the economic position of no impact of income on 


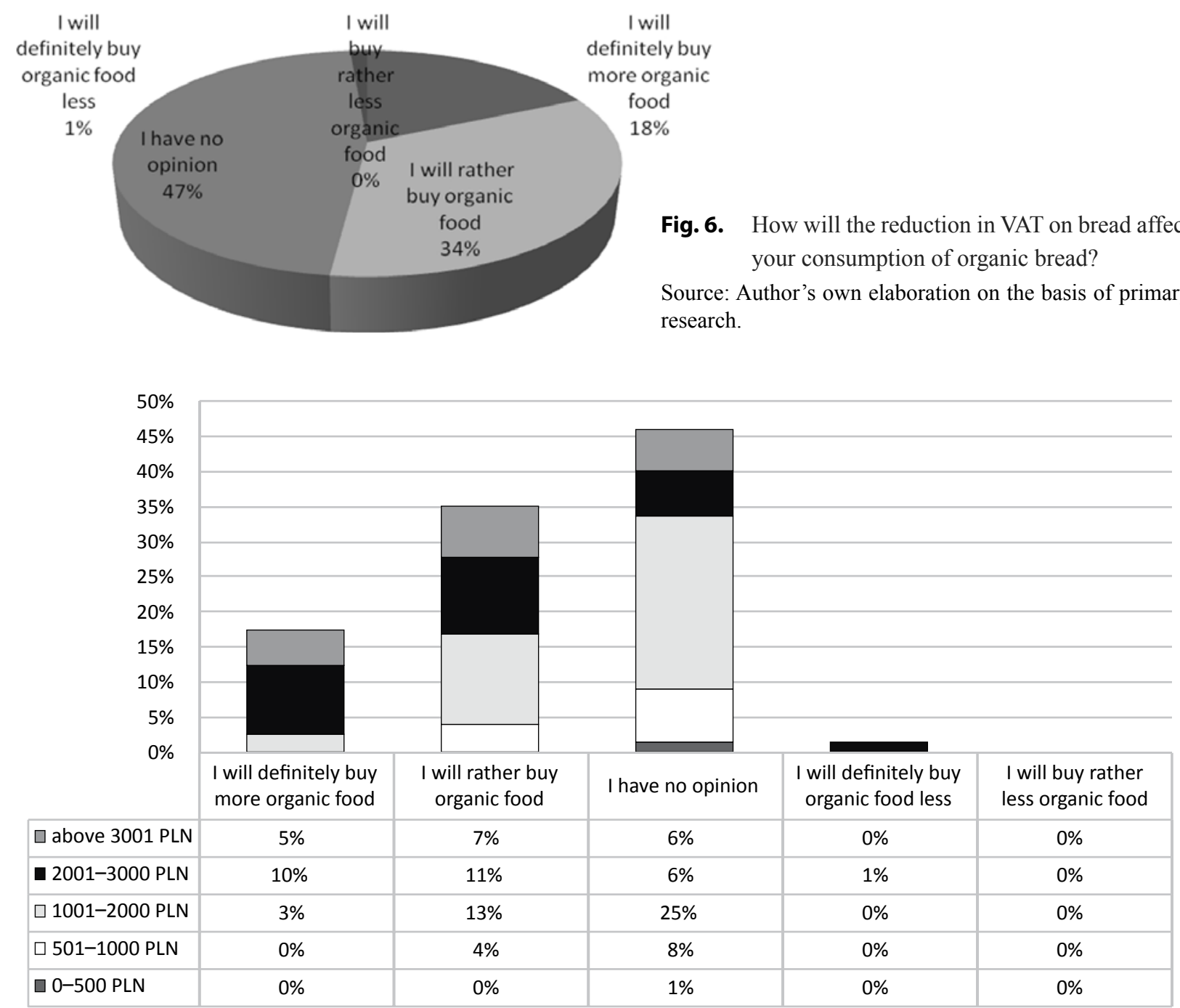

Fig. 7. How will the reduction in VAT on bread affect your consumption of organic bread? Due to net income per person in the family

Source: Author's own elaboration on the basis of primary research.

the demand for basic goods. In the case of bread, there is no such dependence, either (Fig. 7).

In turn, respondents rated the reduction of VAT on cakes to $5 \%$ as being rather positive. One-third did not have an opinion. All the data is presented in Figure 8.

Interest in a lower tax rate on cakes, including organic cakes, was shown by respondents aged 18-25. As many as $29 \%$ of those respondents evaluate this change positively (Fig. 9).

The respondents were also unable to assess the impact of a reduction in VAT on cakes on the purchase of organic cakes. However, almost the same number of respondents stated that they would rather buy more organic food than before. The data is illustrated in Figure 10.

Among the respondents who declared that they would rather buy more organic cakes after the VAT rate reduction, most had an income range of PLN 1,001$-2,000(14 \%)$ and PLN 2,001-3,000 (10\%). Between these variables there was also a moderate positive relationship of 0.41339 , which means that as income increases, consumer opinions become more neutral. 


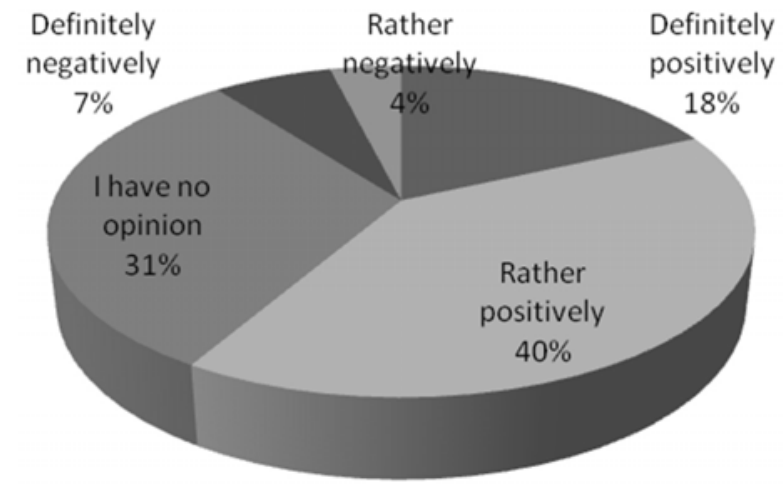

Fig. 8. How do you assess the reduction in VAT rates on cakes and confectionery to $5 \%$ since July 2020 ?

Source: Author's own elaboration on the basis of primary research.
The respondents assessed the reduction of VAT on tropical fruit to $5 \%$ in a very similar way. They stated that the reduction is definitely positive or rather positive. The data is illustrated in Figure 11.

According to respondents, public subsidies received by organic farmers support the production of organic food in a determined or moderate way. Figure 12 shows the exact results. Among consumers who assessed their support of farmers through subsidies as average, the largest number of respondents were people with an income range of PLN 1,001-2,000 (15\%) and 2,001-3,000 (10\%).

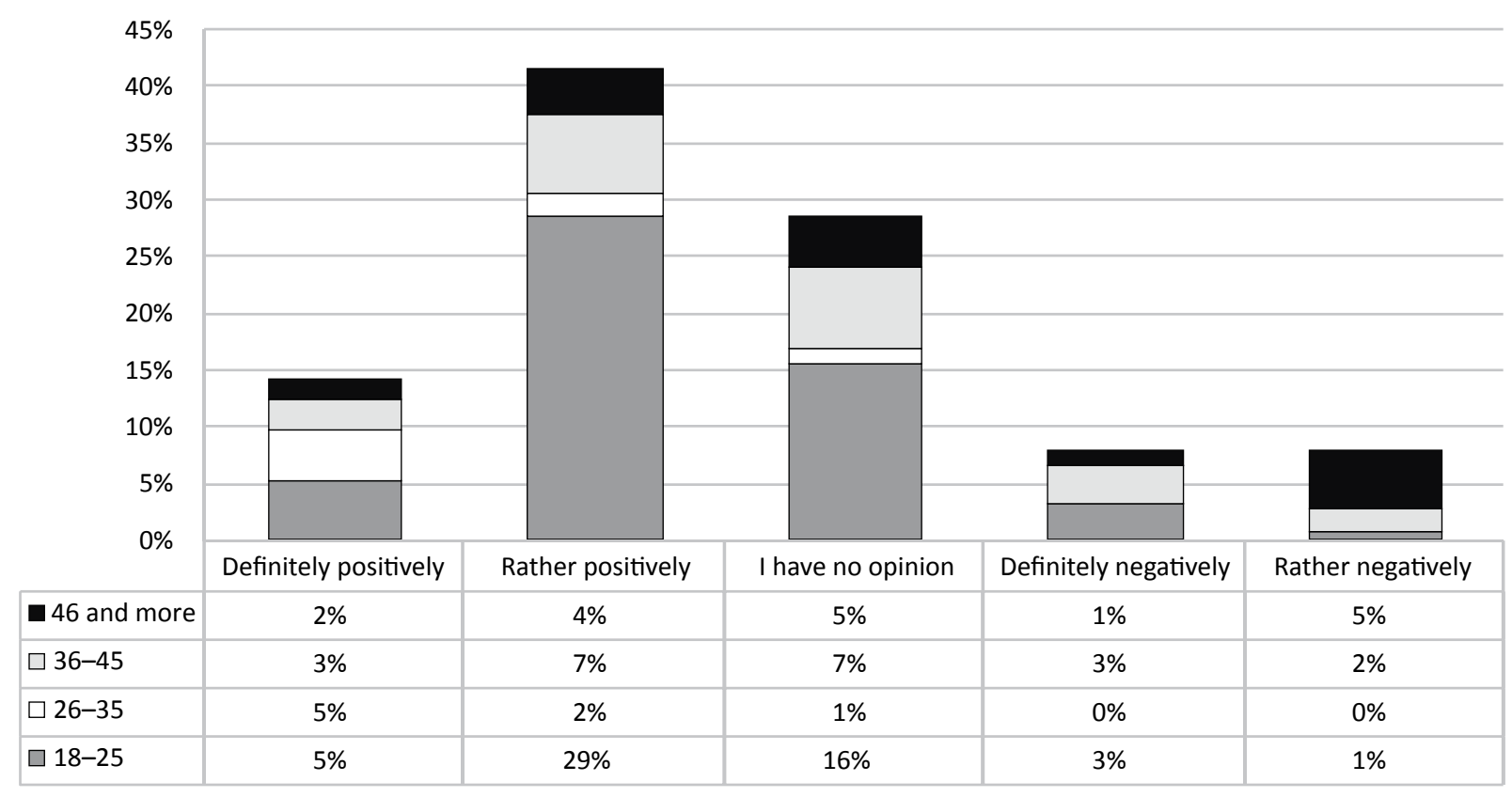

Fig. 9. How do you assess the reduction in VAT rates on cakes and confectionery to 5\% since July 2020? Age of respondents Source: Author's own elaboration on the basis of primary research.

Fig. 10. How will the VAT reduction on cakes affect your consumption of organic cakes?

Source: Author's own elaboration on the basis of primary research.

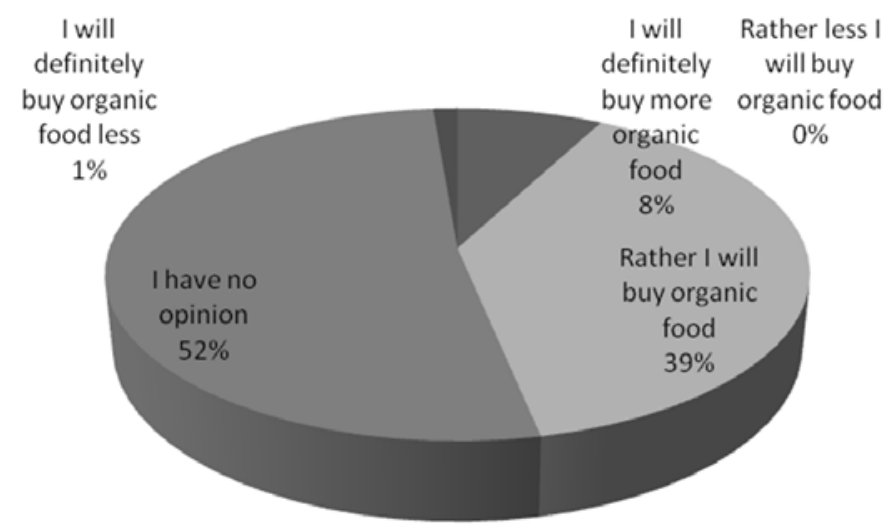




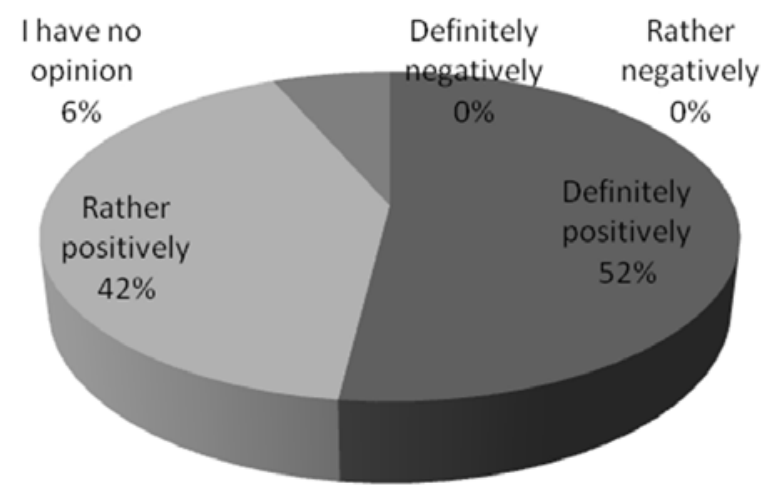

Fig. 11. How do you assess the reduction of VAT rate on tropical fruit from 8 to $5 \%$ in July 2020 ?

Source: Author's own elaboration on the basis of primary research.

The respondents agreed that information is the most desirable tool for promoting organic food, and that this kind of instrument should be used by public authorities. Figure 13 illustrates the full structure. Tax tools took second place among the indications.

On the other hand, according to respondents, preferential VAT taxation of organic food would have a rather positive impact on the consumption of organic food. The remaining indications are reflected in Figure 14.

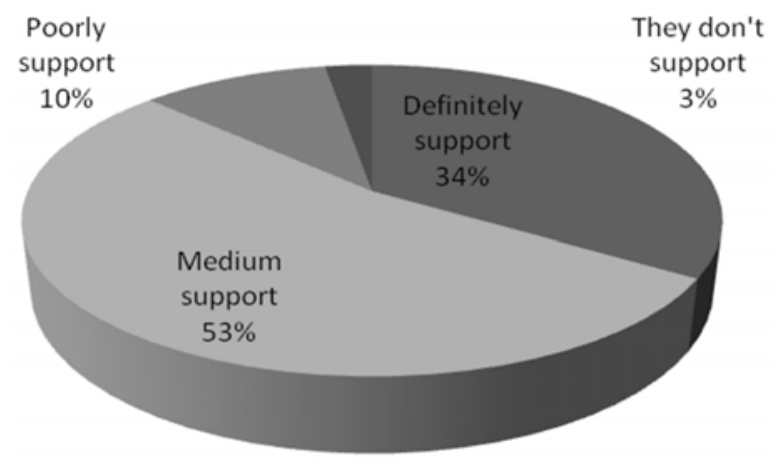

Fig. 12. The degree of support for organic farmers in Poland by public subsidies

Source: Author's own elaboration on the basis of primary research.

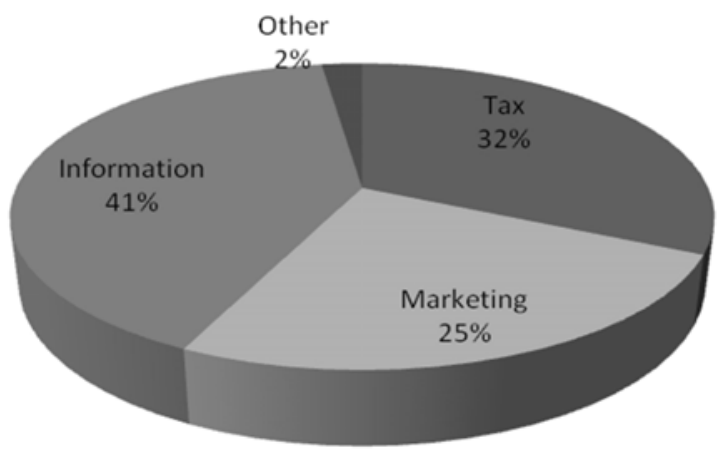

Fig. 13. Tools that should be used by public authorities to increase your consumption of organic food

Source: Author's own elaboration on the basis of primary research.

Fig. 14. The impact of preferential VAT on organic food on your organic food purchases

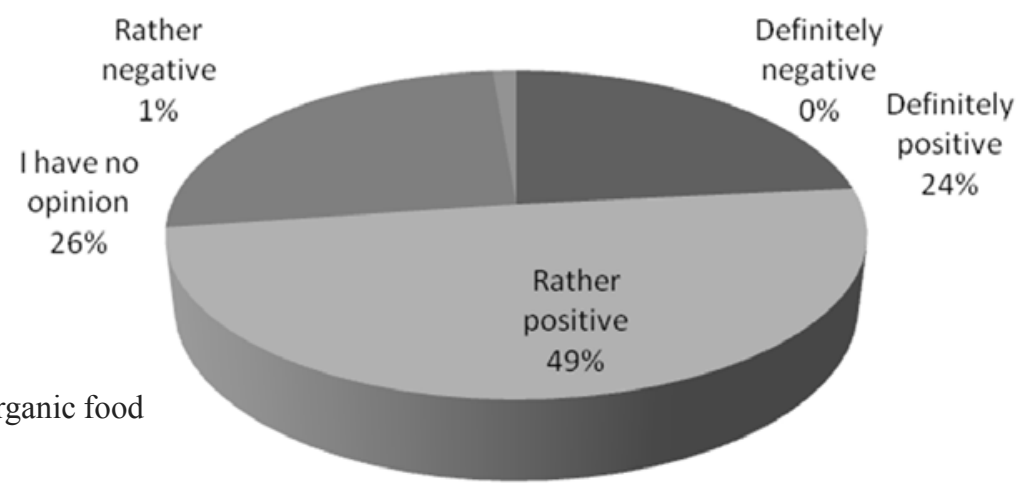

Source: Author's own elaboration on the basis of primary research. 


\section{DISCUSSION}

Looking at the results of the research, it should be stated that consumers mostly buy organic food and are aware of how organic food differs from that produced with traditional methods. Healthiness and lack of preservatives in bio food are, for consumers, the most important motives for its purchase. All the changes in VAT rates which were introduced in July 2020 met with a positive assessment from consumers. It is worth noting that all the questions concerned the reduction of VAT rates. Since July 2020, some food items have a higher VAT rate than before. However, these are products that are not purchased as often as bread, fruit or cakes, therefore, they were not included in the questionnaire. It applies in particular to some spices, ice for food purposes or lobsters, octopi, etc.

Another consideration to the undertaken research is the fact that a reduction in the VAT rate will not always result in a reduction of the product price. Retail chains can raise net prices and consumers will not notice the change in the portfolio. This consumer awareness has been verified by particular questions. As it turned out, equalization of the VAT rate on all types of bread will not be a motivator for consumers to buy organic bread. These results are not surprising because most often, bread with a short expiry date bought in bakeries has already had a 5\% rate for a long time. Only the rate of bakery products that had an expiry date over 14 days was reduced. It is these items that have benefited from the change. Due to the fact that they are bought less often than traditional bread, this change will not affect the purchase of organic bread.

To a greater extent, respondents reacted to a reduction in the VAT rate on pastry goods. They assessed the change positively and expressed their willingness to buy organic cakes. Interestingly, the reduction of the VAT rate on tropical fruit was assessed particularly positively by consumers. Fruit is a frequently purchased food item among Polish consumers. However, it is worth noting that the majority of tropical fruit in Polish stores are also imported from countries outside the European Union. Such items are beyond EU legislation, which makes it difficult for consumers to verify whether they are purchasing certified organic food.
Consumers agreed that to a large and medium extent, public subsidies financially support organic farmers in Poland. However, respondents indicated marketing and tax instruments as the most effective government tools to support the consumption of organic food in Poland. There are a lot of campaigns promoting organic food, both commercial and governmental, on the Polish market. Confirmation of consumer interest in a lower VAT rate on organic food is the answer to the last question. The vast majority indicated a positive impact of this change on organic food purchases.

\section{CONCLUSIONS}

The results of this survey have clearly demonstrated the impact of tax instruments on consumer purchasing decisions in the area of organic food, and the goal of the research project was accomplished. However, since the survey was carried out before the introduction of the new tax rates, it would be advisable to repeat the survey during the period of application of the changes.

\section{REFERENCES}

Angowski, M., Bujanowicz-Haraś, B. (2019). Consumers on organic food market - factors determining the choice of diary products. Acta Scientiarum Polonorum. Oeconomia, 18 (2), 5-12, https://doi.org/10.22630/ ASPE.2019.18.2.14

Doba, K., Roszyk, S., Zmudziński, W. (2019). Regional products and traditional and organic food: coexistence or competition? Journal of Agribusiness and Rural Development, 1 (51), 15-20, http://doi.org/10.17306/ J.JARD.2019.01145

Grzybowska-Brzezińska, M., Gorlowa, O. (2019). Conditions for the establishment of distribution channels in the organic food market. Journal of Agribusiness and Rural Development, 1 (51), 35-42, http://doi.org/10.17306/ J.JARD.2019.01121

Hermaniuk, T. (2018). Postawy i zachowania konsumentów na rynku ekologicznych produktów żywnościowych. Handel Wewnętrzny, 2, 189-199.

Hovhannisyan, V., Kondaridze, M., Bastian, Ch., Shanoyan, A. (2020). Empirical Evidence of Changing Food Demand and Consumer Preferences in Russia. Journal of Agricultural and Applied Economics, 52 (3), 480-501, https://doi.org/10.1017/aae.2020.13 
Kacprzak, M., Wielewska, I. (2019). Organic food market and growing needs and awareness of the contemporary consumer. Scientific Papers of Silesian University of Technology. Organization and Management Series, 139, 179-191, http://doi.org/10.29119/16413466.2019.139.13

Katz, M., Campbell, B., Liu, Y. (2019). Local and Organic Preferences: Logo versus Text. Journal of Agricultural and Applied Economics, 51, 328-347, https://doi. org/10.1017/aae.2019.4

Kucher, A., Heldak, M., Kucher, L., Fedorchenko, O., Yurchenko, Y. (2019). Consumer willingness to pay a price premium for ecological goods: a case study from Ukraine. Environmental \& Socio-economic Studies, 7 (1), 38-49, https://doi.org/10.2478/environ2019-0004

Łuczka, W. (2019). Changes in the behavior of organic food consumers. Ekonomia i Środowisko, 3 (70), 140-153, https://doi.org/10.34659/2019/3/40

Mie, A., Andersen, H.R., Gunnarsson, S., Kahl, J., Kesse-Guyot, E., Rembiałkowska, E., Quaglio, G., Grandjean,
P. (2017). Human health implications of organic food and organic agriculture: a comprehensive review. Environmental Health, 6 (111), 1-22, https://doi.org/10.1186/ s12940-017-0315-4

Moon, W., Chang, J.B., Asirvatham, J. (2017). Measuring public preferences for multifunctional attributes of agriculture in the United States. Journal of Agricultural and Applied Economics, 49 (2), 273-295, https://doi. org/10.1017/aae.2016.43

Nestorowicz, R. (2018). Asymetria wiedzy a rozwój rynku żywności ekologicznej w Polsce. Handel Wewnętrzny, 5, 212-224.

Willis, D., Carpio, C.E., Boys, K.A. (2016). Supporting local food system development through food price premium donations: a policy proposal. Journal of Agricultural and Applied Economics, 48 (2), 192-217, https://doi. org/10.1017/aae.2016.10

Wydawnictwo C.H. Beck (n.d.). Zmiany w VAT wprowadzane od 1.4.2020 r. Retrieved from https://gov.legalis. pl/zmiany-w-vat-wprowadzane-od-1-4-2020-r [accessed 11.02.2020].

\section{ODDZIAtYWANIE INSTRUMENTÓW PODATKOWYCH NA RYNEK ŻYWNOŚCI EKOLOGICZNEJ W POLSCE}

\section{STRESZCZENIE}

Niniejszy artykuł stanowi analizę i ocenę oddziaływania instrumentów podatkowych na rynek żywności ekologicznej w Polsce. Oceny dokonano na podstawie danych pierwotnych pozyskanych w ramach autorskiego badania ankietowego przeprowadzonego na mieszkańcach województwa śląskiego. W Polsce stawki podatku VAT na żywność różnią się w zależności od kodu klasyfikacji produktu: mogą być 23\%, 8\% lub 5\%. Żywność ekologiczna nie została potraktowana wyjątkowo. Wprowadzone w lipcu 2020 roku zmiany w stawkach podatkowych ściśle określonych artykułów spożywczych są dosyć istotne. Ich wpływ na zakupy żywności ekologicznej określiły wyniki badania ankietowego. Celem artykułu jest zatem ocena oddziaływania stawki podatku VAT na rynek żywności ekologicznej w Polsce.

Słowa kluczowe: żywność organiczna, podatki konsumpcyjne, rynek żywności, VAT 